\title{
Pengaruh Model Pembelajaran Terhadap Kemampuan Pemecahan Masalah
}

\author{
Seruni \\ Universitas Indraprasta PGRI
}

\section{INFO ARTICLES}

Article History:

Received: 08-12-2018

Revised: 11-12-2018

Approved: 20-12-2018

Publish Online: 30-12-2018

Key Words:

Model Learning, Problem-Solving Ability

\section{(c) () ()}

This article is licensed under a Creative Commons AttributionShareAlike 4.0 International License.

\begin{abstract}
The purpose of this research is to know the influence of model learning of mathematics problem solving ability against learners Class VII in SMP Bogor Ibnu'Aqil. The methods used in this research was quasi experiment method. Whereas, sampelnya retrieval techniques is by random sampling technique with 60 students total sample taken from 2 classes, namely 30 students from the class of experiments are given treatment using cooperative learning model of type Two Stay Two Stray (TSTS) and 30 students from the class of the control that is named the treatment using a model of learning ekspositori. Instrument in this study using reserved test essay totalling 7 problem after tested the validity of. Processing the data using SPSS 16.0 obtained test data requirements are nrmal and homogeny. The results of hypothesis testing come by nila sig 0.05 , then < Ho is rejected, so it can be inferred that there was influence model of learning ability of mathematics problem solving towards learners in particular on the material covered.
\end{abstract}

\begin{abstract}
Abstrak: Tujuan dari penelitian ini adalah untuk mengetahui pengaruh model pembelajaran terhadap kemampuan pemecahan masalah matematika peserta didik kelas VII di SMP Ibnu'Aqil Bogor. Metode yang digunakan dalam penelitian ini adalah metode quasi eksperimen. Sedangkan, teknik pengambilan sampelnya adalah dengan teknik random sampling dengan jumlah sampel 60 peserta didik yang diambil dari 2 kelas yaitu 30 peserta didik dari kelas eksperimen yang diberi perlakuan menggunakan model pembelajaran kooperatif tipe Two Stay Two Stray (TSTS) dan 30 peserta didik dari kelas kontrol yang diberi perlakuan menggunakan model pembelajaran ekspositori. Instrument dalam penelitian ini menggunakan soal tes essay yang berjumlah 7 soal setelah diuji validitas. Pengolah data dengan menggunakan SPSS 16.0 didapat uji persyaratan data bersifat nrmal dan homogeny. Hasil pengujian hipotesis didapat nila sig < 0.05 , Maka Ho ditolak, sehingga dapat disimpulkan bahwa terdapat pengaruh model pembelajaran terhadap kemampuan pemecahan masalah matematika peserta didik khususnya pada materi segiempat.
\end{abstract}

Correspondence Address: Jl. Raya Tengah No. 80 Kelurahan Gedong Pasar Rebo Jakarta Timur, Indonesia. e-mail: seruni@unindra.ac.id.

How to Cite (APA ${ }^{\text {th }}$ Style): Seruni. (2018). Pengaruh Model Pembelajaran Terhadap Kemampuan Pemecahan Masalah. JKPM (Jurnal Kajian Pendidikan Matematika), Vol 4 (1), 35-42.

Copyright: Seruni, (2018)

Competing Interests Disclosures: The authors declare that they have no significant competing financial, professional or personal interests that might have influenced the performance or presentation of the work described in this manuscript. 


\section{Pendahuluan}

Dalam suatu negara, pendidikan memiliki peranan penting untuk menjamin kelangsungan hidup negara dan bangsa, karena pendidikan merupakan wadah untuk meningkatkan kualitas sumber daya manusia. Hal ini sejalan dengan pendapat Karomah (dalam Leonard, 2015: 52) yang mengatakan bahwa: "Pendidikan merupakan kunci utama dalam upaya peningkatan kesejahteraan dan kemakmuran rakyat. Pendidikan dapat memajukan suatu bangsa". Banyak faktor yang dapat mempengaruhi rendahnya kualitas pendidikan di Indonesia. Mulyasa (2013:3) mengatakan,

"Sedikitnya terdapat tiga syarat utama yang harus diperhatikan dalam pembangunan pendidikan agar dapat berkontribusi terhadap peningkatan kualitas sumber daya manusia (SDM) yakni: (1)Sarana gedung, (2) buku yang berkualitas, (3) guru dan tenaga pendidik yang professional".

Permasalahan yang sering terjadi dalam kegiatan pembelajaran adalah peserta didik kurang memahami pembelajaran yang disampaikan oleh guru, salah satunya disebabkan oleh cara guru mengajar yang membosankan sehingga peserta didik menjadi malas untuk belajar. Terutama pada pelajaran matematika. Matematika masih dianggap pelajaran yang cukup sulit bagi peserta didik karena selalu berhubungan dengan angka-angka dan rumus yang harus dihafal. Susilawati (dalam Leonard, 2015:81) mengatakan bahwa "saat ini, pelajaran matematika masih dicitrakan sebagai mata pelajaran tersukar dan terkesan ditakuti oleh sebagian besar Peserta didik". Hal ini sejalan dengan pengamatan yang peneliti lakukan di sekolah yang sedang peneliti teliti yaitu di SMP Ibnu Aqil, menunjukkan bahwa peserta didik masih mengalami kesulitan pada pelajaran matematika. Hal ini dapat dilihat dari rata-rata nilai UAS kelas 7 semester ganjil Tahun ajaran 2015-2016, KKM yang harus dicapai Peserta didik adalah 6,8 tetapi rata-rata peserta didik kelas 7 semester ganjil Tahun ajaran 2015-2016 yaitu 5,6.

Memperhatikan permasalahan diatas, rendahnya minat peserta didik terhadap pelajaran matematika disebabkan karena selama ini proses pembelajaran didominasi oleh guru, yakni guru sebagai sumber utama pengetahuan. Peserta didik hanya sebagai pendengar pasif dalam proses pembelajaran, sehingga peserta didik kurang dituntut untuk memahami konsep matematika secara mandiri tanpa harus terpaku terhadap penjelasan guru. Peserta didik cenderung menghafal soal dan rumus yang digunakan untuk memecahkan masalah matematika, sehingga mereka bingung apabila diberikan jenis soal yang berbeda. Hal ini yang membuat peneliti ingin melakukan penelitian lebih lanjut, apakah model pembelajaran dapat mempengaruhi kemampuan pemacahan masalah peserta didik?. Tujuannya adalah untuk mengetahui seberapa besar pengaruh model pembelajaran terhadap kemampuan pemecahan masalah dan seberapa tepat model pembelajaran yang kita ambil dalam meningkatkan kemampuan pemecahan masalah peserta didik.

Salah satu model pembelajaran yang diduga dapat digunakan untuk meningkatkan kemampuan pemecahan masalah peserta didik dan pembelajarannya tidak terpaku hanya pada penjelasan guru adalah model pembelajaran kooperatif tipe Two Stay Two Stray (TSTS). Sejalan dengan Jarolimek \& Parker (dalam Lyana, 2013: 9) yang mengatakan bahwa:

"Pembagian kelompok dalam pembelajaran cooperative tipe Two Stay Two Stray memperhatikan kemampuan akademis Peserta Didik. guru membuat kelompok yang 
heterogen dengan alasan memberi kesempatan Peserta Didik untuk saling mengajar (peer tutoring) dan saling mendukung, meningkatkan relasi dan interaksi antar ras, etnik dan gender serta memudahkan pengelolaan kelas karena masing- masing kelompok memiliki Peserta Didik yang berkemampuan tinggi, yang dapat membantu teman lainnya dalam memecahkan permasalahan dalam kelompok".

Kemampuan pemecahan masalah sangat dibutuhkan peserta didik dalam menyelesaikan berbagai macam soal yang diberikan oleh guru. Makmun dalam Rahayu (2008:9) menjelaskan bahwa dalam belajar memecahkan masalah, peserta didik dihadapkan pada berbagai permasalahan yang akan membuatnya berusaha untuk menggunakan serta menghubungkan pengetahuan-pengetahuan yang telah dimilikinya. Hal ini juha diungkapkan Nasution dalam Faulina (2008 : 9-10) yang menjelaskan bahwa memecahkan masalah dapat dipandang sebagai proses dimana peserta didik mengemukakan kombinasi aturan-aturan yang telah dipelajarinya terlebih dahulu yang digunakan untuk memecahkan masalah yang baru. Memecahkan masalah bukan sekedar menerapkan aturan-aturan yang perlu diketahui, tetapi menghasilkan pelajaran baru, dalam memecahkan masalah peserta didik berpikir, mencoba hipotesis dan bila berhasil memecahkan masalah itu peserta didik dapat mempelajari sesuatu yang baru. Jadi, semakin banyak peserta didik dapat menyelesaikan banyak masalah maka peserta didik akan memiliki banyak kemampuan dalam memcahkan masalahnya dalam kehidupan sehari-hari. Dengan demikian, kemampuan pemecahan masalah adalah kemampuan menggunakan kekuatan sendiri yang mengaplikasikan matematika dalam menyelesaikan masalah dalam pembelajaran maupun kehidupan sehari-hari.

\section{METODE}

Metode penelitian yang digunakan dalam penelitian ini adalah metode kuasi eksperimen dengan mengadakan serangkaian perlakukan secara langsung terhadap sampel. Berikut ini akan di gambarkan secara skematis pemikirannya sebagai berikut :

Tabel 1. Desain Penelitian

\begin{tabular}{lcc}
\hline Kelompok & Perlakuan & Hasil \\
\hline Eksperimen & $\mathrm{X}_{1}$ & $\mathrm{Y}_{1}$ \\
Kontrol & $\mathrm{X}_{2}$ & $\mathrm{Y}_{2}$ \\
\hline
\end{tabular}

Populasi target dalam penelitian ini adalah seluruh Peserta Didik SMP Ibnu Aqil. Populasi terjangkau dalam penelitian ini adalah seluruh Peserta Didik kelas VII SMP Ibnu Aqil, yang terdiri dari 236 Peserta Didik yang terbagi menjadi enam kelas.Yaitu kelas VII-A sampai VII-F. Supardi (2013: 26) menyatakan bahwa "Sampel adalah bagian dari populasi yang mempunyai ciri-ciri atau keadaan tertentu yang akan diteliti”. Maka sampel dalam peniltian ini kelas VII-A dengan jumlah Peserta Didik 30 orang sebagai kelas eksperimen dan kelas VII-B dengan jumlah Peserta Didik 30 orang sebagai kelas kontrol di SMP Ibnu Aqil. Arikunto (2006: 133) menyatakan bahwa "Teknik sampling harus dilakukan sedemikian rupa sehingga diperoleh sampel yang benar-benar dapat berfungsi sebagai sampel, atau dapat menggambarkan keadaan 
populasi yang sebenarnya”. Penelitian ini menggunakan teknik random sampling atau penarikan sampel berkelompok. Peneliti terlebih dahulu mengklasifikasikan peserta didik yang menjadi sampel berdasarkan kelas. Kemudian dipilih secara random sampling untuk menentukan kelas eksperimen dan kelas kontrol. Setelah menetapkan kelas VII A sebagai kelas eksperimen dan kelas VII B sebagai kelas kontrol, peneliti kembali memilih secara random sampling peserta didik yang akan dijadikan sampel. Dan hasilnya ditetapkan kelas eksperimen adalah kelas VII A yang berjumlah 30 orang dan kelas kontrol adalah kelas VII B yang berjumlah 30 orang yang terpilih dengan cara undian. Pengambilan data pada setiap variabel dalam penelitian ini terdiri dari Variabel bebas yaitu model pembelajaran (Model pembelajaran kooperatif tipe Two Stay Two Stray (TSTS) dan model pembelajaran ekspositori) dengan memberikan perlakuan berbeda pada dua kelas yang berbeda tapi dalam satu tingkatan dan variabel terikat yaitu kemampuan pemecahan masalah matematika dengan memberikan soal essay tentang segiempat sebanyak 7 soal yang sudah di validasi.

\section{HASIL}

Tabel 2. Deskripsi Data

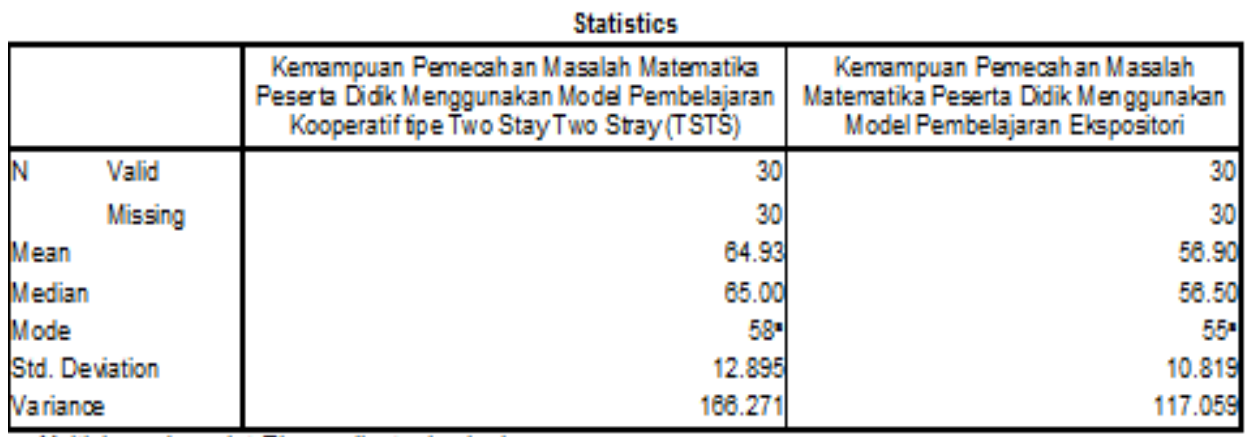

a. Multiple modes exist. The smallest value is shown

Tabel 3. Uji Normalitas

\begin{tabular}{|c|c|c|c|}
\hline \multicolumn{4}{|c|}{ One-Sam ple Kolmogorov-Smimov Test } \\
\hline & & \begin{tabular}{|c|} 
Kemampuan Pemecahan Masalah \\
Matematka Peser ta Didik Menggunakan \\
Model Pembelajar an Kooperatif tipe Two \\
StayTwo Stray (TSTS)
\end{tabular} & $\begin{array}{c}\text { Kemampuan Pemecahan Masalah } \\
\text { Matematika Peserta Didik } \\
\text { Menggun akan Model } \\
\text { Pembelajaran Ekspositori }\end{array}$ \\
\hline \multirow{3}{*}{$\begin{array}{l}\text { N } \\
\text { Normal Parameters" }\end{array}$} & & 30 & 30 \\
\hline & Mean & 64.93 & 56.90 \\
\hline & Std. Deviation & 12.895 & 10.819 \\
\hline \multirow[t]{3}{*}{ Most Extreme Differences } & Absolute & .125 & .131 \\
\hline & Positive & .086 & .131 \\
\hline & Negative & -.125 & -.104 \\
\hline Kolmogorov-Smirnov Z & & .686 & .717 \\
\hline Asymp. Sig. (2-tailed) & & .734 & .682 \\
\hline & & & \\
\hline
\end{tabular}

Kriteria :

Sig > 0.05, Maka data berdistibusi normal

Sig $<0.05$, Maka data tidak berdistribusi normal 
Tabel 4. Uji Homogenitas

\section{Levene's Test of Equality of Error Variances ${ }^{\mathrm{N}}$}

DenendentVariable:KemamouanPemecahan Masalah Matematika

\begin{tabular}{|c|r|r|r|}
\hline $\mathrm{F}$ & $\mathrm{df1}$ & $\mathrm{df} 2$ & Siq. \\
\hline 1.577 & 1 & 58 & .214 \\
\hline
\end{tabular}

Tests the null hypothesis that the error variance of the dependent variable is equal across groups.

a. Design: Intercept $+X$

Kriteria :

Sig $>0.05$, Maka data homogen

Sig $<0.05$, Maka data tidak homogen

Tabel 5. Uji Hipotesis

\begin{tabular}{|c|c|c|c|c|c|c|c|c|c|c|}
\hline \multicolumn{11}{|c|}{ Independent Samples Test } \\
\hline & & \multicolumn{2}{|c|}{$\begin{array}{l}\text { Levene's Test for Equality of } \\
\text { Variances }\end{array}$} & \multicolumn{7}{|c|}{ t-test for Equality of Means } \\
\hline & & \multirow[t]{2}{*}{ 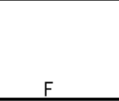 } & \multirow[b]{2}{*}{ Siq. } & \multirow[b]{2}{*}{ t } & \multirow[b]{2}{*}{ df } & \multirow[b]{2}{*}{ Siq. (2-tailed) } & \multirow[b]{2}{*}{$\begin{array}{c}\text { Mean } \\
\text { Difference }\end{array}$} & \multirow[b]{2}{*}{$\begin{array}{c}\text { Std. Error } \\
\text { Difference }\end{array}$} & \multicolumn{2}{|c|}{$\begin{array}{c}95 \% \text { Confidence Interval of the } \\
\text { Difference }\end{array}$} \\
\hline & & & & & & & & & Lower & Upper \\
\hline $\begin{array}{l}\text { Kemampuan Pemecahan } \\
\text { Masalah Matematika }\end{array}$ & $\begin{array}{l}\text { Equal variances } \\
\text { assumed } \\
\text { Equal variances not } \\
\text { assumed }\end{array}$ & 1.577 & .214 & $\begin{array}{l}2.614 \\
2.614 \\
\end{array}$ & $\begin{array}{r}58 \\
56.301 \\
\end{array}$ & $\begin{array}{r}.011 \\
.011 \\
\end{array}$ & $\begin{array}{l}8.033 \\
8.033\end{array}$ & $\begin{array}{l}3.073 \\
3.073\end{array}$ & $\begin{array}{l}1.882 \\
1.878 \\
\end{array}$ & $\begin{array}{l}14.185 \\
14.189 \\
\end{array}$ \\
\hline
\end{tabular}

\section{Kriteria :}

Sig (2-tailled) $<0.05$, Maka Ho ditolak

Sig (2-tailled) $>0.05$, Maka Ho diterima

\section{PEMBAHASAN}

Berdasarkan Hasil Penelitian diatas didapat bahwa nilai rata-rata kemampuan pemecahan masalah matematika peserta didik yang menggunakan model pembelajaran kooperatif tipe Two Stay Two Stray (TSTS) lebih tinggi dibandingkan rata-rata kemampuan pemecahan masalah matematika peserta didik yang menggunakan model pembelajaran ekspositori. Hal ini bisa dikatakan bahwa model pembelajaran kooperatif tipe Two Stay Two Stray (TSTS) memberikan dampak yang lebih baik daripada peserta didik yang diberikan model pembelajaran ekspositori. Dilihat dari uji hipotesis didapat nilai sig (2-tailled) sebesar 0.011 lebih kecil dari 0.05, maka Ho ditolak artinya bahwa model pembelajaran mempengaruhi kemampuan pemecahan masalah matematika peserta didik. Sejalan dengan penelitian yang dilakukan Nurhikmayati (2018) yang berjudul Pengaruh Model Two Stay Two Stray Terhadap Kemampuan Pemecahan Masalah Matematik Siswa mengatakan bahwa pertama proses pembelajaran dengan model Two Stay Two Stray pada kelas eksperimen dapat dikatakan berhasil. Langkah-langkah pembelajaran kooperatif tipe Two Stay Two Stray diterapkan dengan baik selama proses pembelajaran di kelas VIII pada materi lingkaran, (2) Terdapat pengaruh positif pada penggunaan pembelajaran kooperatif tipe Two Stay Two Stray terhadap kemampuan pemecahan 
masalah matematik siswa, dan (3) Secara umum sebagian besar siswa memiliki sikap positif terhadap pelajaran matematika dan terhadap pembelajaran Two Stay Two Stray. Hal ini menerangkan bahwa model pembelajaran dapat mempengaruhi dan meningkatkan kemampuan pemecahan masalah matematika peserta didik.

Kemampuan pemecahan masalah merupakan kemapuan yang harus dimiliki oleh peserta didik. Peserta didik akan dikatakan pintar atau pandai jika mampu dalam memecahkan masalah. Menurut Widjajanti (2009) bahwa pemecahan masalah adalah proses yang digunakan untuk menyelesaikan masalah. Dalam proses ini peserta didik harus memiliki strategi yang tepat dalam menyelasaikan masalah agar dapat terselesaikan dengan baik. Sunendar (2017) mengatakan salah satu cara yang efektif dalam pemecahan masalah adalah dengan memahami masalah secara teliti, membedakan mana yang merupakan hal yang diketahui dan mana yang merupakan masalah yang harus dipecahkan. Karena itu kegiatan pemecahan masalah akan menjadi lebih baik jika dilakukan secara berkelompok dengan cara berdiskusi dan saling bertukar pendapat dalam memahami masalah yang diberikan. Model pembelajaran kooperatif yang tepat dalam menunjang strategi dalam memecahkan masalah ini adalah model pembelajaran kooperatif tipe $T$ wo Stay Two Stray (TSTS)

Pada pembelajaran yang menggunakan model pembelajaran kooperatif tipe Two Stay Two Stray (TSTS) membuat anak lebih mandiri dan mampu menyampaikan materi kepada teman-temannya sehingga peserta didik mudah memahami materi yang telah diberikan, sehingga dapat meningkatkan kemampuan pemecahan masalah peserta didik. Sejalan dengan yang dikatakan Lie dalam Lyana (2013: 10) bahwa "Model pembelajaran Two Stay Two Stray (Dua Tinggal Dua tamu) merupakan suatu model pembelajaran dimana Peserta Didik belajar memecahkan masalah bersama anggota kelompoknya, kemudian dua Peserta Didik dari kelompok tersebut bertukar informasi ke dua anggota kelompok lain yang tinggal dalam kelompoknya. Dalam model pembelajaran Two Stay Two Stray (Dua Tinggal Dua Tamu), Peserta Didik dituntut untuk memiliki tanggungjawab dan aktif dalam setiap kegiatan pembelajaran”. Hal ini memberi kesempatan kepada kelompok untuk mengembangkan hasil informasi dengan kelompok lainnya. Selain itu, struktur model pembelajaran kooperatif tipe Two Stay Two Stray (TSTS) ini memberi kesempatan kepada kelompok untuk membagikan hasil kesempatan kepada kelompok lain. Banyak kegiatan belajar mengajar yang diwarnai dengan kegiatan individu. Peserta didik bekerja sendiri dan tidak diperbolehkan melihat pekerjaan peserta didik yang lain. Padahal dalam kenyataan hidup diluar sekolah, kehidupan dan kerja manusia saling bergantung satu dengan yang lainnya.

Hasil penelitian ini memberikan sebuah jalan terang untuk membuat peserta didik lebih tertarik untuk terus mempelajari matematika yang sebagian besar kurang disukai karena kerumitannya dan sekaligus membuat peserta didik untuk terus berinteraksi dengan kelompok lain. Secara garis besar, penelitian ini memberikan hasil bahwa kemampuan pemecahan masalah matematika materi Segiempat yang diajar menggunakan model pembelajaran kooperatif tipe Two Stay Two Stray (TSTS) lebih tinggi dibandingkan dengan kemampuan pemecahan maslah peserta didik yang diajar menggunakan model pembelajaran ekspositori. Hal ini menunjukan bahwa penggunaan model pembelajaran kooperatif tipe Two Stay Two Stray (TSTS) dapat memberikan pengaruh yang baik dalam peningkatan kemampuan pemecahan masalah dalam pembelajaran dan juga dalam kehidupan sosial mereka. Karena dalam model pembelajaran kooperatif tipe Two Stay Two Stray peserta didik dituntut untuk dapat berkomunikasi dengan peserta didik yang lain. Hal 
ini sejalan dengan pendapat Roger dan Johnson (Suprijono, 2013:58) yang mengatakan bahwa, "Tidak semua belajar kelompok bisa dianggap pembelajaran kooperaif. Untuk mencapai hasil yang maksimal, lima unsur dalam model pembelajaran kooperatif harus diterapkan. Lima unsur tersebut adalah: (1) Positive interdependence (saling ketergantungan positif), (2) Personal responsibility (tanggung jawab perseorangan), (3) Face to face promotive interaction (interaksi promotif), (4) Interpersonal skill (komunikasi antar anggota), (5) Group processing (pemprosesan kelompok)". Unsur- unsur inilah yang kemudian akan bermanfaat untuk peserta didik selain bahan ajar matematika yang sudah mereka pelajari dari pendidik.

\section{SIMPULAN}

Berdasarkan hasil penelitian dapat disimpulkan bahwa ada pengaruh model pembelajaran terhadap kemampuan pemecahan masalah matematika peserta didik. Terlihat dari pengolahan data rata-rata kemampuan pemecahan masalah matematika kelompok peserta didik yang diberi model pembelajaran kooperatif tipe Two Stay Two Stray (TSTS) lebih tinggi daripada rata-rata kemampuan pemecahan masalah matematika kelompok peserta didik yang diberi model pembelajaran ekspositori atau dengan kata lain pemberian model pembelajaran kooperatif tipe Two Stay Two Stray (TSTS) mempunyai pengaruh terhadap kemampuan pemecahan masalah matematika peserta didik SMP Ibnu'Aqil Bogor.

Berdasarkan simpulan dapat dikemukakan beberapa saran sebagai berikut: (1) Guru hendaknya memberikan pemahaman kepada peserta didik bahwa pembelajaran matematika itu bermakna dalam kehidupan seharihari, sehingga peserta didik sendiri akan mencari dan menyukai pelajaran matematika, (2) Guru hendaknya memberikan motivasi dan menciptakan suasana yang menyenangkan agar peserta didik merasa nyaman dan termotivasi untuk bertanggung jawab dalam mempelajari mata pelajaran matematika, (3) Guru hendaknya membimbing peserta didik yang tidak mengerti pelajaran, terutama peserta didik yang tidak aktif sehingga mereka dapat memahami materi pelajaran dengan baik, (4) Guru hendaknya memberikan masalah- masalah yang menarik yang dapat merangsang Peserta Didik berpikir dalam proses pembelajaran, (5) Guru hendaknya menggunakan model pembelajaran kooperatif tipe Two Stay Two Stray (TSTS) dalam materi segiempat dan lingkaran agar dapat meningkatkan kemampuan pemecahan masalah matematika peserta didik, (6) Peserta didik diharapkan menyukai pelajaran matematika dan berlatih untuk memiliki daya juang yang tak kenal lelah, karena matematika bukanlah hal yang mudah untuk dipahami. Oleh karena itu. Dibutuhkan kerja keras dan rasa tanggung jawab yang lebih besar dibandingkan pelajaran lain, (7) Peserta didik diharapkan memanfaatkan waktu yang ada untuk berlatih mengerjakan soal-soal latihan matematika, agar terbiasa, dan (8) Peserta didik diharapkan berperan aktif dalam proses kegiatan belajar mengajar (KBM) dan tidak malu untuk bertanya. 


\section{DAFTAR RUJUKAN}

Arikunto, S.(2006). Prosedur Penelitian Suatu Pendekatan Praktik. Jakarta: Rineka Cipta.

Faulina, Herlin. (2008). Meningkatkan Aktivitas Belajar Matematika Siswa Kelas VIII-C Melalui Metode Pemecahan Masalah. Bandar Lampung: Universitas Lampung.

Karomah,Anistin dan Indah Lestari. (2015). Pengaruh Strategi Pembelajarn Metakognitif Terhadap Hasil Belajar Matematika. In Leonard (Editor). EduResearch: Raise The Standard, Vol. 1, hal 51-78. Jakarta: Unindra Press.

Lyana, Elin. (2013). Pengembangan Cooperative Learning Teknik Two Stay Two Stray (TSTS) dalam pembelajaran sejarah untuk meningkatkan hasil (Penelitian Tindakan Kelas di kelas VII H SMP Negeri 2 Purwakarta). Skripsi.Universitas Pendidikan Indonesia.

Mulyasa. (2013). Menjadi Guru Professional (menciptakan pembelajaran kreatif dan menyenangkan). Bandung: PT Remaja Rosdakarya.

Nurhimayati, I. (2018). Pengaruh Model Two Stay Two Stray terhadap Kemampuan Pemecahan Masalah Matematik Siswa. Jurnal THEOREMS (The Original Research of Mathematics), 3(1): 49-57. https://doi.org/10.5281/zenodo.1319284.

Rahayu, S. (2008). Analisis Kemampuan Siswa dalam Memecahkan Masalah pada Subkonsep Pencemaran Lingkungan Melalui Metode Studi Kasus. Bandung: Universitas Pendidikan Indonesia

Sunendar, A. (2017). Pembelajaran Matematika kontemporer. Bandung: UPI.

Supardi. (2013). Hasil belajar matematika Peserta Didik ditinjau dari interaksi tes formatif uraian dan kecerdasan emosional. Formatif: Jurnal Ilmiah Pendidikan MIPA, 3(2): 78-96.

Suprijono, Agus. (2013). Cooperative Learning. Yogyakarta: Pustaka Pelajar.

Widjayanti, D.B. (2009). Kemampuan Pemecahan Masalah Matematis Mahasiswa Calon Guru Matematika: Apa dan Bagaimana Mengembangkannya. Disajikan dalam Seminar Nasional FMIPA UNY Tanggal 5 Desember 2009. http://www.scribd.com/doc/35776081/teori-vygotky (online 20/05/2016) 